\title{
An Evaluation on Climate Change Awareness in Tourism Sector in the Mekong Delta Region of Vietnam
}

\author{
Van Da Huynh ${ }^{1} \&$ Awais Piracha ${ }^{2}$ \\ ${ }^{1}$ School of Social Sciences and Humanities, Can Tho University, Can Tho, Vietnam \\ ${ }^{2}$ School of Social Sciences and Psychology, Western Sydney University, Sydney, Australia \\ Correspondence: Van Da Huynh, School of Social Sciences and Humanities, Can Tho University, Campus 2, 3/2 \\ Street, Ninh Kieu District, Can Tho City, Vietnam. Tel: 84-91-923-3876. E-mail: hvda@ctu.edu.vn
}

Received: July 19, 2019 Accepted: September 10, 2019 Online Published: October 24, 2019

doi:10.5539/ass.v15n11p93 URL: https://doi.org/10.5539/ass.v15n11p93

\begin{abstract}
This study analyses the awareness level of key stakeholders about climate change impacts on the tourism sector in the Mekong Delta. In the regional context, stakeholders include tourism authorities, tourism businesses and tourists. The study investigates the following aspects of climate change awareness in the tourism sector in the region: 1) the climate change knowledge of tourism authorities, tourism businesses and tourists; 2) sources of awareness as well as quality of these sources; 3 ) climate change awareness education and action. As well as descriptive statistics, means and significant analysis, cross tabulation analysis is also used in this study to compare the awareness between stakeholder groups. The study found that the awareness level of tourism stakeholders in the region is at stage two of environmental awareness model of Partanen-Hertell et al. (Partanen-Hertell, Harju-Autti, Kreft-Burma, \& Pemberton, 1999).
\end{abstract}

Keywords: awareness, awareness education, climate change, climate change awareness, Mekong Delta, tourism

\section{Introduction}

Climate change is one of the biggest challenges of the $21^{\text {th }}$ century. Climate records for the Mekong Delta show that climate change is happening at a pace of change that is increasing (ICEM, 2009). Several studies by research institutions and the Mekong Delta provinces (ICEM, 2009; Ministry of Natural Resources and Environment, 2008, 2016; Oranop-na-Ayuthaya, 2015; Tran, 2012, 2017) indicated climate changes in recent decades consists of rising temperatures, increasing rainfall, salt water intrusion further inland and most importantly, sea level rise. Also, more extreme weather events have been recorded.

Mekong Delta of Vietnam offers a wide range of tourism destinations including natural heritage that showcases the region's biodiversity, cultural heritage from southern Vietnam's rich prehistory, early historic and $20^{\text {th }}$ century wartime historic sites. Around the Delta, there are five national parks, dozens of conservation areas and hundreds of freshwater fruit gardens. The Delta is covered by dense network of rivers, canals and islets. Moreover, dozens of floating markets, pagodas and temples serve as tourist attractions. Climate change has put a strong pressure on the conservation and development of these values for tourism development. Climate change awareness evaluation and education are on the top priority in recent efforts to tackle climate change. Hence, increasing awareness amongst people is one of the most important missions, as well as a tool to stimulate action and adaptation.

\section{Problem Statement}

The benefit of environmental awareness is recognized by numerous authors and studies. Environmental awareness contributes to the better management of environmental resources (Bohdanowicz, 2006; Palmer, Suggate, Robottom, \& Hart, 1999; Stabler \& Goodall, 1997) and awareness development can help in preparing and implementing climate change adaptation measures (Klein et al., 2001). Moreover, Partanen-Hertell et al. (1999) pointed out that different stages of life can impact on different level of environmental awareness. In addition, socio-economic indicators (such as education, age, gender, social status), would affect environmental awareness. It can be concluded from the above that raising environmental awareness is an important factor in the process of environment protection and that awareness varies in different regions and communities. This study will figure out how awareness do stakeholders in the tourism sector and the government authorities in the delta 
region have of climate change and its impacts on tourism? Which factors may be influence to that awareness?; and how awareness of stakeholders could improve?.

\section{Review of Environmental Awareness and Climate Change Awareness}

Effective climate change adaptation processes require a high level of awareness from the relevant stakeholders. Environmental awareness and more specifically 'climate change awareness' can be defined in various different ways. Shahid (2012) argues that 'Environmental awareness of individuals, organisations and firms is an indicator of how people respond to the negative impacts on their surrounding environment'. Partanen-Hertell et al. (1999) also indicate that 'Environmental awareness can be defined as a combination of motivation, knowledge and skills about the environment'. Ziadat (2010) agrees that 'Environmental awareness is some kind of knowledge that can be obtained through one's perception'. Therefore, environmental awareness is a product of education, whether formal, practical or traditional, and hence can be increased through a careful combination of these.

Partanen-Hertell et al. (1999) came up with an earlier environmental awareness model. There are four different stages and three elements in this model (Figure 1). Environmental awareness often occurs when people begin to experience the threats and drawbacks from the surrounding environment. Before that experience, people consider they are the 'master of nature'. In the first stage, motivation to acquire environmental awareness arises from a threat to health. Due to the absence of knowledge of the area, the public indicates that environmental problem solving is the mission of academics, non-governmental organizations or international organizations in the field of environment. The first action to raise the environmental awareness level is to educate and train the key politicians, authorities, scientists and business decision-makers. In the second step, society already functions basic environmental legislation and administrative structures. The necessary environmental monitoring systems have been applied and infrastructures, systems and relevant technologies for waste management are increasingly utilized. However, there is no connection between different environmental protection solutions to have better results. As a consequence, the main focus is directed to separate environmental issues. In the third stage, there are the intensive development of legislation and administration, environmental monitoring and facilities for environmental purposes. Therefore, environmental issues and concerns are now an important part of the professional and public awareness. Hence, development leads towards more sustainability because of this increasing environmental awareness. The outcomes of these actions are that economy and production of the society becomes stronger because of the stable sustainable welfare. At the last stage, environmental awareness becomes an integral part of professional skills and everyday life choices. It moves toward a holistic environmental awareness.
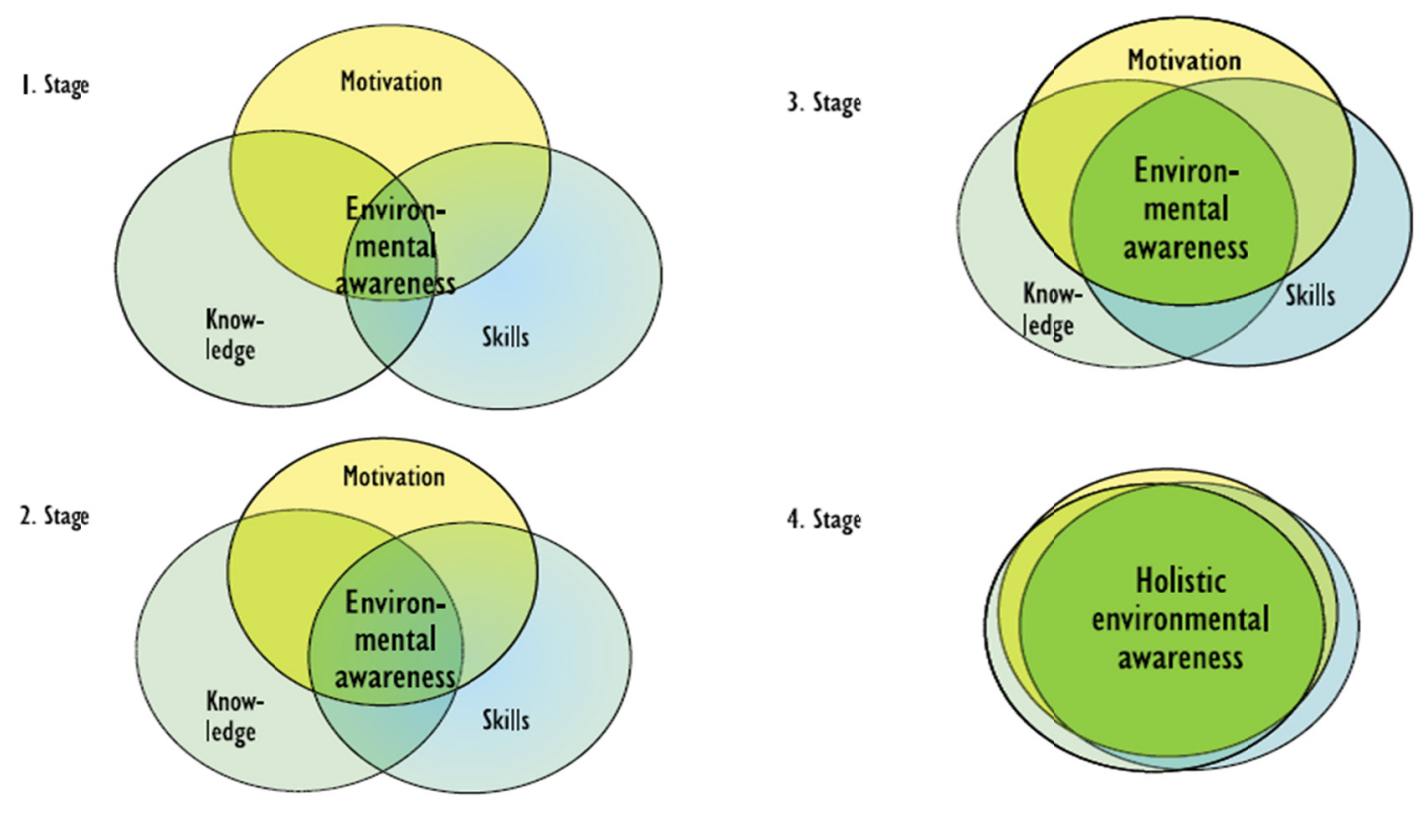

Figure 1. Four stage of environmental awareness Source: Partanen-Hertell et al. (1999, p. 23) 
This model has been applied in the Baltic Sea area via questionnaire distribution (Partanen-Hertell et al., 1999). A set of questionnaires were distributed to the participants from various backgrounds in Baltic Sea area. The author discovered that three different regions have different level of awareness: Subregion $1=$ Russia, Belarus, Ukraine at 1st stage, subregion 2 = Estonia, Latvia, Lithuania, Poland, the Czech Republic and Slovakia at the 2nd stage, and subregion 3 = Denmark, Finland, Germany, Norway and Sweden at 3rd stage. The model mentions environmental awareness at a large scale. This model can be applied on a number of predominant environmental issues such as ozone depletion, loss of biodiversity, water and air pollution and climate change impacts. This model also considers stakeholder participation. Stakeholders from many backgrounds are mentioned in the model. However, as this model is applied for developed countries,, Buloshi and Ramadan (2015) and Odjugo (2013) has proven that awareness level may depend on the level of development of a country. Therefore, this model will need some adjustments when applied in developing countries such as Vietnam. Also, the model may not need all four stages as one cannot expect Vietnam to achieve at the last stage. Another issue with this model is that it applies to the whole society, not just to a certain targeted sector. Thus, it needs to be re-evaluated when used for a certain sector, such as tourism.

The Environmental Behaviour model is another model that is concerned with environmental awareness. This model was developed by Grob (1995). The model identifies connections between environmental awareness and other factors such as personal philosophical values, perceived control, environmental behavior and emotions. Grob (1995) applied this model in Switzerland, conducting a random survey to evaluate the environmental attitudes of individuals. Focus groups were also used in the study (green car drivers and traditional car driver groups). The study discovered that there are strong connections between behaviours and environmental perspectives. The strength of this model is that it can evaluate many relationships between environmental perspectives and behaviours of certain person. However, it should include socio-economic, geographical and cultural effects with environmental behaviours as these elements can play a vital role in process of environmental awareness development.

In addition, Arlt, Hoppe, and Wolling (2011) introduced a new environmental awareness model called The Variable Model. The model describes the connections between media usage of people, climate change problems awareness and climate-related behavioural intentions. The two main components of this model are climate-related behavioural intentions and climate problem awareness. This model has been applied in Germany. The research discovered that although contribute some positive impacts on climate change awareness media does not always develop awareness on climate change directly. However, this model does not explain how different media services impact on climate change awareness. In addition, unavailability of further data can make it less reliable.

\section{Climate Change Awareness in Practice}

Climate change awareness in developing countries has also received much attention. Numerous initiatives to improve climate change awareness have taken place in developing countries such as in India, Nigeria and Vietnam.

In India, there are two typical programs concerning climate change awareness and adaptation. The first project took place in Chitradurga in Karnataka district. In this initiative, the farmers were encouraged to cultivate alternative crops instead of only traditionally grown groundnut. The outcomes indicated that farmers of this area had lower levels of vulnerability and higher adaptive capacity to climate change impacts. Then, farmers in this area aware that changing in the cultivation behavior would benefit for both of their incomes and environments (O’Brien et al., 2004).

Another project is from International Council for Local Environmental Initiatives South Asia (ICLEI 2008 cited in (Shahid, 2012)). This organization supported the Change Management Unit of Kolkata Urban Services for the poor program in creating awareness on climate change among urban managers in West Bengal, India. This program developed a climate change roadmap for Kolkata Metropolitan Area. It helped the leaders of the city make better planning decisions for public buildings and construction projects. In 2008, the Indian government had launched the National Action Plan on Climate Change including 8 missions in which strategic knowledge for climate change is a very important element (Government of India, 2008).

In Nigeria, a program concerning climate change awareness and adaptation was launched in 2011 with the support of African Technology Policy Studies Network. The project is called Climate Change Awareness and Adaptation in the Niger Delta Region of Nigeria. The most important objectives of this program were: 1) to evaluate the level of awareness of local community around the impacts of climate change; 2) to enhance the capacities of farmers in the Niger Delta Region of Nigeria to adapt to climate change impacts; 3) to make 
recommendations on policies for building climate change resilience in Nigeria; 4) to identify available extension services relating to climate change and adaptation strategies, and; 5) to determine problems associated with adapting to effects of climate change (Nzeadibe, Egbule, Chukwuone, \& Agu, 2011). The program came up with a potential adaptive strategy for the farming communities in the research area. Due to the fact that this project took place in a delta region of a developing country, it could serve as a good reference for similar areas such as Mekong Delta of Vietnam.

The Vietnamese government, in association with some research institutions and organizations, has carried out studies relating to climate change awareness and adaption. Recently, USAID introduced the 'Mekong Adaptation and Resilience to Climate Change' project. This project covers a wide range of areas from natural eco-systems, livelihoods to agriculture and fisheries in the Mekong River Delta basin (USAID, 2015). In 2014, there were two sub-projects that sought to raise climate change awareness of communities and women in the lower Mekong Basin (Oranop-na-Ayuthaya, 2015; Oranop-na-Ayuthaya \& Lehman, 2015).

These project outcomes show that the level of climate change awareness of communities and women in the region is relatively low (less than $50 \%$ ). However, action plan and education could raise the awareness significantly up to $85 \%$. This project concludes that awareness about climate change amongst people in the Mekong Delta region could improve by further education and adaptation strategies.

\section{Research Methods}

This study employs both quantitative and qualitative methodologies for data collection, analysis and representation to approach the aims of the research. Therefore, a mixed method approaches has been adopted in the study involving observation, survey questionnaires and in-depth interviews with the local tourism authorities, tourism companies, and tourists. Data was mostly collected from primary sources. The secondary data is mostly from literature on the demographic characteristics of the region.

Due to the differences in background of respondents and purposes for information collection about climate change-tourism concern, a set of different questionnaires were designed for this study. These questionnaires include questionnaires for leaders of local tourism authorities, managers of tourism companies and tourists. The study focuses on these three target groups since they are the most important stakeholders in Mekong Delta tourism. There are two main parts of these questionnaires: closed questions and open-ended questions. In these questionnaires, stakeholders are asked about their knowledge, experiences and ideas on the climate change awareness issues as they relate to tourism in Mekong River Delta.

In total, a total of 124 questionnaires were conducted by the study, including: Local tourism authorities (Tourism Departments at the 13 cities and provinces, Mekong Delta Tourism Association, and the Southwestern Steering Committee): 15 questionnaires. Tourism companies (Hotels and sites, mainly focusing on principal tourist attractions of Can Tho City, Tien Giang, Ben Tre, Ca Mau and Kien Giang provinces): 30 questionnaires. Tourists (Including international tourists and domestic tourists): 79 questionnaires. 36 international tourists and 43 domestic tourists were selected by convenience sampling method at Can Tho City, Tien Giang, Ben Tre, Ca Mau and Kien Giang provinces.

To supplement information collected with the questionnaires, in-depth interviews were conducted with local tourism authorities and tourism companies. The interviews were semi-structured, with open-ended questions following the themes of the research questions: What awareness do stakeholders in the tourism sector and the government authorities in the delta region have of climate change and its impacts on tourism? 38 interviews were conducted for this study, including 15 interviews with local tourism authorities and 23 interviews with tourism companies.

\section{Result}

\subsection{Climate Change Knowledge of Stakeholders in Tourism Sector in the Mekong Delta}

Climate change knowledge has been found to depend on various factors such as gender, ages, level of education, social status, income and availability of information (Buloshi \& Ramadan, 2015; Mandleni \& Anim, 2011; Maponya, Mpandeli, \& Oduniyi, 2013; Nzeadibe et al., 2011; Odjugo, 2013). Nowadays, with the popularity of information technology and a variety of communication methods, the information is much quicker and easier to transfer between communities. In the Mekong Delta, as a case in point, $100 \%$ of respondents had already 'heard' about the existence of the climate change.

However, the question is how much people know about climate change poses important lessons for future dissemination of action plans and strategies to mitigate negative effects in the future. Figure 2 indicates that only $15.6 \%$ know a great deal about climate change. On the other hand, nearly $85 \%$ know something or only have 
heard of climate change. Clearly, there is a marked absence of individuals with a high level of knowledge about climate change. Climate change knowledge in the delta is at similar levels to other developing countries. For example, in the city of Lahore of Pakistan, only $12.7 \%$ of city officials knew a great deal and $87.3 \%$ had only heard a small amount of or knew something about climate change (Shahid, 2012).

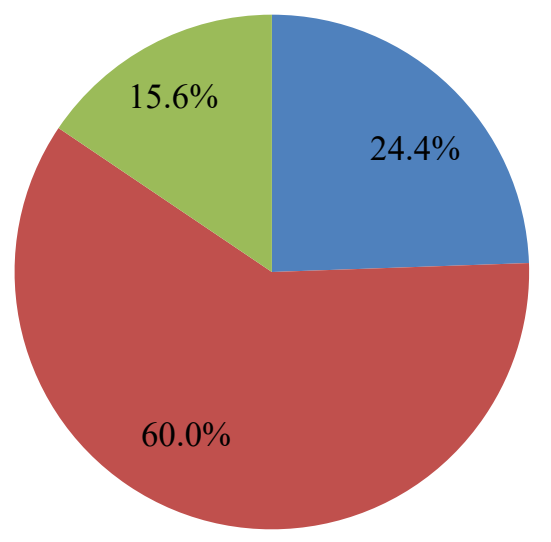

Only heard

- Know something about it

Know a great deal about it

Figure 2. Hear about climate change to what extent $(n=45)$ Source: Questionnaire interview in 2016

Above mentioned literature indicates that awareness levels depend on many variables such as gender and educational qualifications. A further examination was conducted to check if this theory is matching with regional profile of the Mekong.

Table 1. To what extent by gender $(n=45)$

\begin{tabular}{|c|c|c|c|c|c|}
\hline & & \multicolumn{3}{|c|}{ To what extent } & \multirow[b]{2}{*}{ Total } \\
\hline & & Only heard & Know something about it & Know a great deal about it & \\
\hline \multirow{2}{*}{ Gender } & Male & 8 & 15 & 4 & 27 \\
\hline & Female & 3 & 12 & 3 & 18 \\
\hline \multicolumn{2}{|c|}{ Total } & 11 & 27 & 7 & 45 \\
\hline
\end{tabular}

Chi-square test: $\chi 2=0.988, \mathrm{df}=2, \mathrm{p}>0.05 ;$ Insignificant relation

Source: Questionnaire interview in 2016

As can be seen in Table 1 and Table 2, the chi-square test supports the argument that there is no significant association between gender and qualification and extent to which participants know about climate change. Due to the differences in the method of sampling the population, this finding is different to the outcome of Buloshi and Ramadan (2015) and Maponya et al. (2013) which identified that gender and qualification is important in climate awareness levels. This study has targeted specific group of respondents (tourism authorities and businesses) and relied on the convenience sample method while other studies targeted the whole population and rely on a randomly sample method.

Table 2 . To what extent by qualification $(n=45)$

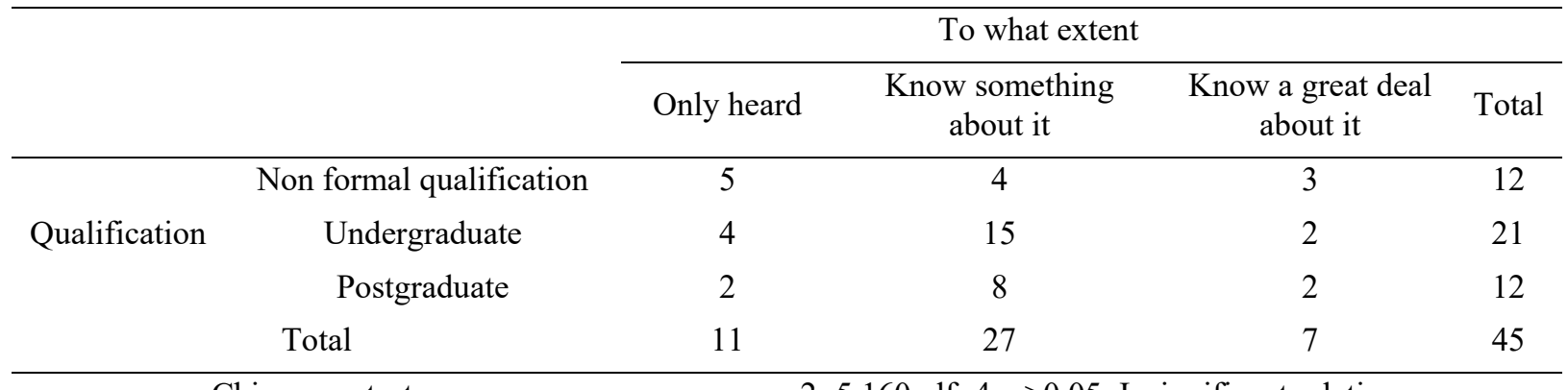

Chi-square test:

$\chi 2=5.160, \mathrm{df}=4, \mathrm{p}>0.05 ;$ Insignificant relation

Source: Questionnaire interview in 2016

In the survey questionnaire, an open-ended question was asked to establish the level of understanding that 
stakeholders held about climate change issues. The general question: 'What do you know about climate change?' was posed. The outcome was that most of respondents knew one or only a few consequences or causes of climate change. Not many of them could communicate an in-depth knowledge about climate change. For example, these responses were:

'Climate change is the unstable change of weather, for example: strong sunny conditions, long lasting rain, sudden storms' (B08, questionnaire, 2016)

'Climate change is the irregular climate, broken natural law, bad impact to human life' (B19, questionnaire, 2016)

'Climate change impacts to human life environment, for example: sea water level rise, floods, drain' (L11, questionnaire, 2016).

Even though these respondents could not draw a full picture of climate change, such knowledge of the practical consequences, disruptions to annual climate rhythms and increases in weather irregularities from a non-climate professional is notable.

A further analysis of knowledge types of impacts of climate change to tourism sector in the region is shown in Table 3. The respondents in this survey are local authorities and tourism business leaders who hold the highest level of education among the community. However, level of awareness about climate change among these sectors were only average. Around $60 \%$ of respondents had already heard about the possible future effects of climate change.

Table 3. Already heard about the possible future effects of climate change in the Mekong Delta $(\%)(n=45)$

\begin{tabular}{ccccccccc}
\hline & $\begin{array}{c}\text { Sea } \\
\text { level } \\
\text { rise }\end{array}$ & $\begin{array}{c}\text { Erosion } \\
\text { increase }\end{array}$ & $\begin{array}{c}\text { Intrusion of } \\
\text { salt into } \\
\text { river/ground } \\
\text { water }\end{array}$ & $\begin{array}{c}\text { More } \\
\text { storms }\end{array}$ & $\begin{array}{c}\text { Abnormal } \\
\text { rain }\end{array}$ & $\begin{array}{c}\text { Hotter } \\
\text { temperatures }\end{array}$ & $\begin{array}{c}\text { Negative } \\
\text { impacts on } \\
\text { ecosystem }\end{array}$ & $\begin{array}{c}\text { Public/private } \\
\text { utilities may } \\
\text { get damaged }\end{array}$ \\
\hline No & 42.2 & 48.9 & 31.1 & 31.1 & 13.3 & 15.6 & 37.8 & 31.1 \\
Yes & 57.8 & 51.1 & 68.9 & 68.9 & 86.7 & 84.4 & 62.2 & 68.9 \\
\hline
\end{tabular}

Source: Questionnaire interview in 2016

The percentage of awareness is also different for types of impacts. Respondents are mostly aware of abnormal rain and hotter temperatures. Around $85 \%$ of respondents had heard about abnormal rain and hotter temperatures as the possible future effects of climate change. Higher intrusion of salt into river/ground water, public/private utilities may get damaged and more storms have moderate awareness in the group at around $69 \%$. Respondents are much less aware of erosion increase, negative impacts on ecosystem and sea level rise. As indicated in the literature, sea level rise is the biggest challenge in the delta. However, the awareness of this threat to the delta is only at one of the lowest level (57.8 \%) among the other principal threats. Beside above principal threats respondents also mentioned other threats as consequences of climate change such as: pollution, disease, and desertification.

The level of climate change awareness has also been examined in some other countries which indicate that there is a big difference of climate change awareness between developed and developing countries. Shahid (2012) demonstrated that climate change awareness amongst Pakistan's officials is relatively low. In this study, around $47 \%$ of local officials in Lahore District of Pakistan were aware of the phenomenon of climate change and whilst half of them had only heard about climate change. Odjugo (2013) indicates in his study $52 \%$ of Nigerians have little knowledge of climate change and only $22 \%$ have much knowledge of climate change. These statistics are still better than a report by Anita and Julie (2009) which reports that only $44 \%$ of people in Sub-Sahara Africa are aware of climate change. In contrast, $90 \%$ of residents in City of Prince George in Canada were at least somewhat concerned about climate change (Picketts, Curry, Déry, \& Cohen, 2013).

Various projects about climate change awareness were conducted in the Mekong Delta. A project entitled 'Climate change awareness of communities in the Lower Mekong Basin' (Oranop-na-Ayuthaya, 2015) reported $45 \%$ people in a rural community knows of climate change and around $50 \%$ of them were concerned about climate change. In another study, 'Women's awareness of climate change in the Lower Mekong Basin' (Oranop-na-Ayuthaya \& Lehman, 2015), only $39 \%$ of women were aware of climate change.

In general, comparison to global outlook awareness level of stakeholders in tourism sector in the Mekong region is at the middle level. This proportion is higher than in other 'developing' countries and yet much lower than 
'developed' ones. In institutional perspective of Mekong, awareness of tourism authorities and businesses seems higher than in local communities and women. This is due to the higher education and social status of these participants. People working in the tourism sector tend to be better educated and have more educational opportunities. Therefore, in general it is evident that they have a better understanding of climate issues.

\title{
6.2 Sources of Awareness and Quality of Climate Change Information Sources in the Mekong Delta
}

Sources of climate information differ according to economic conditions, geography and time. Odjugo (2013) has shown that the main source of climate change awareness education for Nigerians is from radio and television. According to another study, government information and social media are the main channels for climate change information in China (Kuhn \& Yangyong, 2014). In India video media, newspapers and radio are effective ways for raising disaster reduction awareness (Das, 2016). In Baltic Sea region professional environmental events and publications are the most important channels of information and newspapers and magazines are considered as important channels of information (Partanen-Hertell et al., 1999). In almost East European countries television and radio network systems are the main sources of environment information while in many West European countries electronic communication is the most important source of environmental information (Partanen-Hertell et al., 1999).

Climate change information in the Mekong Delta comes from many different sources. Table 4 shows the seven principal channels by climate change information. These figures can be categorized into two main groups. The first group includes following channels: friends/family, conferences/meetings, local government agencies and central government agencies with $26.7 \%, 37.8 \%, 40 \%$ and $40 \%$, people respectively say that they receive climate change information from these channels. The contribution of these sources was relatively low. The second group is a much bigger source of climate change knowledge. It consists of the following channels: newspaper, television and radio and internet with $88.9 \%, 88.9 \%$ and $91.1 \%$, people respectively say that they receive climate change information from these channels. As a result from the above analysis the traditional means of communication (friends/family, conferences/meetings) has less impact than methods utilizing advanced, digital technologies (Internet, Television, radio) for transfer of climate change information to the community. This has important implications for designing a management and mitigation strategy.

Table 4 . Where have you heard about climate change $(\%),(n=45)$

\begin{tabular}{cccccccc}
\hline & $\begin{array}{c}\text { Television, } \\
\text { radio }\end{array}$ & Newspaper & Internet & $\begin{array}{c}\text { Central } \\
\text { Government } \\
\text { agencies }\end{array}$ & $\begin{array}{c}\text { Local } \\
\text { Government } \\
\text { agencies }\end{array}$ & $\begin{array}{c}\text { Friends/ } \\
\text { Family }\end{array}$ & Conferences/Meetings \\
\hline No & 11.1 & 17.8 & 8.9 & 60.0 & 60.0 & 73.3 & 62.2 \\
Yes & 88.9 & 82.2 & 91.1 & 40.0 & 40.0 & 26.7 & 37.8 \\
\hline
\end{tabular}

Source: Questionnaire interview in 2016

Table 5. Trust information about climate change if heard $(\%),(n=45)$

\begin{tabular}{ccccc}
\hline & A scientist & A friend/a family member & Government & Media \\
\hline Less trust & 2.2 & 4.4 & 0 & 0 \\
Somehow trust & 0 & 35.6 & 22.2 & 0 \\
Trust & 13.3 & 44.4 & 40.0 & 40.0 \\
Much trust & 15.6 & 15.6 & 37.8 & 28.9 \\
Trustiest & 68.9 & 0 & 31.1 \\
\hline
\end{tabular}

Source: Questionnaire interview in 2016

\begin{abstract}
Above analysis shows that climate change information could reach its audiences in a number of different ways. Nevertheless, there is a concern that is how much people trust that information. Table 5 lists level of trust of climate change information from differences sources. In this study a five-point Likert style scale was used to survey the level of trust of information from a reporter. It was found that scientists are trusted the most. More than $97 \%$ of people trusted the information that comes from a scientist. It was also noticeable that government and media have high reputation from audiences for one hundred percent. Unfortunately, information provided by a friend or a family member is received less credibly, and only $40 \%$ of people trust information from these informal sources.
\end{abstract}


The above discussion indicates that the climate change awareness education in the Mekong Delta can be distributed through several different channels. Scientists, government representatives and media are the best sources of information that is likely to guide community action. Scientists have the highest reputation meanwhile media is the most effective way to transfer information in the era of mass communication. The analysis also suggests that the information from a scientist or government via the transformation of media is the best way for climate change education in the region.

A mean score analysis is also supported for above argument. Scientist $(M=4.49)$ and government $(M=4.16)$ have the enormous trust from participant while a friend/a family member has less trust $(\mathrm{M}=2.71)$. Although media receive the $3^{\text {rd }}$ place in trust level but the mean is at the high level $(M=3.91)$. Hence, due to the effectiveness and availability of media in this era of communication technology it need to encouragement to use for awareness promotion about climate change. In addition, the standard deviation in this statistic is also relatively low for almost variables $(s<1)$. This means there is not much bias about the quality of a climate change information sources which are being trusted by respondents.

A deeper analysis was conducted with the same sample size respondents on how people are aware of climate change impacts on the tourism sector. The survey found that more than $95 \%$ of respondents were aware of climate change impact to local tourism sector. It is a very high percentage and it is due to the fact that climate change information is very popular in the region. Moreover, climate change is a real threat and already impacts tourism sector of the region.

There is a little difference in awareness between business and leader groups. Local tourism leaders have more awareness than business groups. $100 \%$ leaders indicated their awareness of climate change impacts on local tourism businesses while 28 out of 30 businesses showed the same occasion. Despite of this minor difference, the awareness rate in this group of respondents is acceptable. It seems the climate change awareness education program in tourism sector in the area is highly effective.

The survey also explored the degree of awareness of these of principal stakeholders. The respondents were also asked if they are aware of climate change impact to the tourism sector, then 'To what extent' were they aware. A three-point Likert style scale was applied to ask respondents about the degree to which they are aware of the impact of climate change to local tourism. The results indicate that only about a quarter of them $(25.6 \%)$ were strongly aware. Most of the respondents (72.1\%) were aware and a minority $(2.3 \%)$ has little awareness. As mentioned in the previous session while climate change has strong impacts on local tourism businesses they needs to have a strong awareness from their stakeholders. Therefore, level of the tourism businesses awareness needs to be raised for a more effective climate change adaptation.

One of the biggest debates in climate change research is whether climate change is a result of natural causes or human-made causes. However, amongst the scientific community there is almost worldwide agreement that climate change, though a complex interrelation of natural and human factors, has been driven by dramatic effects of industrialization on the climate system. The result is in the recognition of a new epoch, the Anthropocene, marked by indicators that humans have altered the trajectory of world environmental history so that the idea of something 'natural' has now become contentious. One of the most pressing agendas now is to strategize ways to slow down and mitigate climate change processes by limitation the negative impacts of human activities on environments.

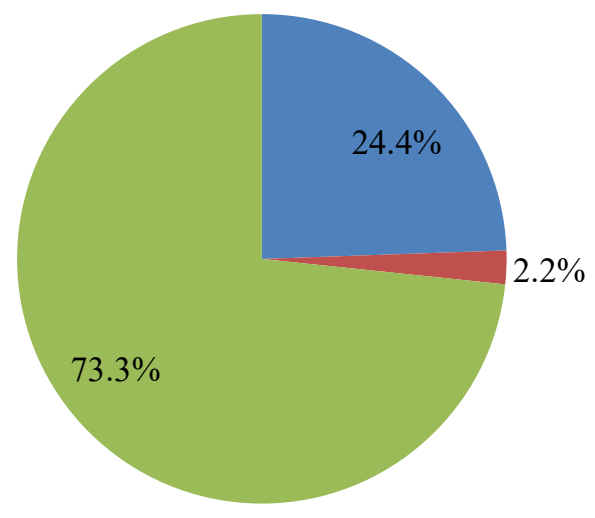

\author{
natural cause \\ - Manmade cause \\ Both natural and manmade \\ causes
}

Figure 3. Main cause of climate change $(\%),(n=45)$

Source: Questionnaire interview in 2016 
In this study, 45 leaders of local tourism authorities and tourism business were surveyed and asked about the main causes of climate change as they perceived. The output is shown in Figure 3. An interesting result is that $2.2 \%$ of respondents indicate climate change result from manmade causes, $24.4 \%$ agrees climate change is from natural causes and a majority of $73.3 \%$ conclude climate change is a result of both manmade and natural causes.

This question aimed to check respondents' knowledge of climate change. The previous analysis figures that people in the Mekong Delta have a relatively high level of awareness of climate change. However, whether the knowledge that they receive is right or wrong is examined through this question. More than a quarter (26.6\%) of respondents answer climate change is a result of only natural or manmade causes. It is not following the worldwide understanding about causes of climate change. Therefore, there is a bias issue in term of climate change information quality. This problem needs an adjustment during climate change education process in the region.

\subsection{Climate Change Awareness Education and Action in Tourism Sector in Mekong Delta}

Anley, Bogale, and Haile-Gabriel (2007) and (Maddison, 2006) argued that improving education is a key to stimulate local action in responding to climate challenges. The former section of this study indicated that there are some outlets for climate change information that facilitate more effective communication that results in better awareness and grounds for action. One of the most important channels is via scientists and organized by central or local governments. The most common academic method used to transfer climate change knowledge in this regard is through consultation, workshops or conferences. In the survey, more than half of respondents $(51.1 \%)$ confirmed that they are used to attend a consultation, workshop or conference about climate change. This proportion is about average but it demonstrates the Vietnamese government's serious efforts in tacking to climate change the condition of a poor country.

Although many actions have been taken to increase the awareness of people in the Mekong region the survey revealed that stakeholders believe central and local government are not doing enough to increase awareness about climate change impacts. This is probably because of the two main reasons. On the one hand, people feel government authorities could offer more social care. On the other hand, people may think that climate change is such a serious issue in the region that it warrants further investment from authorities. As a result it needs more concern from authorities to bridging the gap. In this study only $35.6 \%$ responded that central and local governments are doing enough while $64.4 \%$ commented that central and local governments need to do more in order to promote awareness amongst all stakeholders in the region.

Although the statistic showed an insignificant relation between businesses and authorities groups about the role of central government in tackling climate change there are some differences between them. More than half of the representatives of government authorities indicated that central government is not doing enough while this proportion is more than two-third for the business sector (Table 6). Clearly, due to the difference level in approaching climate information business sector, it claims a more negative outlook on the role of central government on climate change solutions.

Table 6. Central and local governments are doing enough by groups, $(n=45)$

\begin{tabular}{ccccc}
\hline & & \multicolumn{2}{c}{ Central and local governments are doing enough } & Total \\
\cline { 3 - 5 } & & No & Yes & 30 \\
\hline \multirow{2}{*}{ Group number } & Businesses & 21 & 9 & 15 \\
& Authorities & 8 & 7 & 45 \\
\hline \multicolumn{2}{c}{ Total } & 29 & 16 & 45
\end{tabular}

Chi-square test:

$\chi 2=1.212, \mathrm{df}=1, \mathrm{p}>0.05 ;$ Insignificant relation

Source: Questionnaire interview in 2016

The survey also found that there are numerous barriers in promoting climate change awareness among public and professional tourism sectors. Most of respondents believe that a lack of funds, lack of staff and lack of concern are main threats that need to be addressed in promoting awareness of climate change. Other barriers mentioned in the responses are: lack of verified information and lack of knowledge. Table 7 depicts the perceptions of the respondents about the circumstances. It was found that nearly $65 \%$ of respondents agree that a lack of funds and lack of concern has caused difficulties for climate change awareness promoting while nearly $58 \%$ of people mentioned lack of staff is the problem in promoting awareness. In general, it has been recognized 
that to promote awareness about climate change in the tourism sector in the Mekong Delta human resources, financial resources and government and public concern need to be invested significantly for a more effective climate change education program. This finding, to some extent, is relatively matches with the study by Maponya et al. (2013) which identified lack of information, education and assistance as the principal challenges for climate change awareness education.

Table 7. Main barriers need to be removed in promoting awareness of climate change $(\%),(n=45)$

\begin{tabular}{cccc}
\hline & Lack of funds & Lack of staffs & Lack of awareness \\
\hline No & 35.6 & 42.2 & 35.6 \\
Yes & 64.4 & 57.8 & 64.4 \\
\hline
\end{tabular}

Source: Questionnaire interview in 2016

The strong correlation between business and authority in evaluation of main barriers in promoting awareness of climate change presents in Table 8 . There is a huge contrast between them. Authority agrees that lack of funds and staffs are the main barriers of climate change promotion while business indicates a lack of awareness is the main problem.

Table 8 . Main barriers need to be removed in promoting awareness of climate change by group, $(n=45)$

\begin{tabular}{cccccccc}
\hline & \multicolumn{2}{c}{ Lack of funds } & \multicolumn{2}{c}{ Lack of staffs } & \multicolumn{2}{c}{ Lack of awareness } \\
\cline { 3 - 7 } & No & Yes & No & Yes & No & Yes \\
\hline \multirow{2}{*}{$\begin{array}{c}\text { Group } \\
\text { number }\end{array}$} & Businesses & 14 & 16 & 17 & 13 & 7 & 23 \\
\multicolumn{2}{c}{ Total } & 2 & 13 & 2 & 13 & 9 & 6 \\
\hline \multirow{2}{*}{ Chi-square test: } & \multicolumn{2}{c}{\begin{tabular}{l}
$\chi 2=4.849, \mathrm{df}=1, \mathrm{p}<0.05 ;$ \\
\multicolumn{2}{c}{ Significant relation }
\end{tabular}} & $\begin{array}{c}\chi 2=7.697, \mathrm{df}=1, \mathrm{p}<0.05 ; \\
\text { Significant relation }\end{array}$ & $\begin{array}{c}\chi 2=5.867, \mathrm{df}=1, \mathrm{p}<0.05 ; \\
\text { Significant relation }\end{array}$ \\
\hline
\end{tabular}

Source: Questionnaire interview in 2016

Regarding to the methods of climate change awareness education the query should government need to open up more training classes on climate change knowledge is a very important question. The majority of respondents $(95.6 \%)$ agree that government at central and local level need to open training class about climate change. There is no doubt that it is the action that needs to be considered in the process of climate change awareness promotion.

\section{Conclusion: Climate Change Awareness Implications for Tourism Sector in the Mekong Delta}

During the questionnaire and interviews conducting process, the author recognized that some leaders wanted to act but they do not know where to begin. Some leaders want the government to create a master plan for tourism for dealing with climate change issues as it has been done in agriculture and environment sector. Many of them want to increase the level of awareness of tourism business owner's as the principal solution for climate change adaptation before the master plan of tourism to deal with climate change takes effects. It is a bottom up approach and the fastest way that could be doing at the moment. The author also thinks that is a very good idea. It can be implemented straight away.

Data from observations also indicates that some leaders, especially the top leaders consider climate change to be a sensitive issue and do not want to share knowledge. Due to the restrictive communication culture in Vietnam, many elderly leaders (Normally over 55 years old) are closed-minded and they do not want to be in any trouble. Therefore, they wanted to keep all information secret. In contrast, the younger leaders seem much more opened-minded. They want to share their knowledge and discuss the issue widely and without limitation. In the beginning, the author assumed that this fear is a systemic problem but atthe end of the field work, it could be realized as personal and knowledge issues.

Some leaders claimed that climate change is not a tourism concern, which this thesis has demonstrated is not the case. Leaders in Long An and Dong Thap also considered that their location is further in land and may not, therefore, be impacted by climate change. Though many of the direct consequences, such as sea level rise, might not impact further inland, there are likely to be other direct consequences specific to inland regions. Such research remains to be established. However, the preliminary climate change literature in the Mekong Delta shows that even the provinces in upper stream of Mekong Delta will still experience strong impacts from climate change because but with regionally-specific variation. 
The elder respondents have less awareness on this issue. It is due to the lack of knowledge of climate change. The author also asks what kind of communication channels these people use for information. The responses normally are newspapers and television. On the other side, the younger respondents normally rely on internet and social networks as the main channels to update their information.

Private businesses have less awareness than the state-own businesses. At some places, the author even was being regretted to answer by some private businesses because they said that it is not matter on concern for them. Their main business is making money and climate change is something else unfamiliar. They cannot make money from that. Some private businesses assume that climate change cannot impact their income. The state-owned business people normally come from government sector, so they may have a difference view because they receive difference information compared to private business.

Tourists show their concern about the climate change impacts, especially the international tourists. However, many of them do not know the Mekong Delta is one of the most vulnerable regions from climate change. Also, many of them do not know about the impacts of climate change to the Mekong Delta area. Some of them even want to experience a climate change problem as a flagship during their trip in the Mekong Delta. This indicator should be increased during climate change awareness programs in tourism sector.

This study figures that climate change awareness level in the Mekong Delta is at the upper medium level. However, this knowledge is quite general and it needs focus more on tourism perception. To achieve tourism awareness education in the region there are a wide range of choices in terms of communications and channels the choice of which depends on certain audiences and availability. A climate change awareness program in tourism sector is highly recommended when that information come from scientists and governments and distribute through internet or television/radio. The role of central government needs to enhance in business sector in prompting climate change awareness. Therefore, there are many other tasks need to be taken to increase climate change awareness level of tourism stakeholders in the Mekong Delta region.

\section{References}

Anita, P., \& Julie, R. (2009). Awareness of Climate Change and Threat Vary by Region Adults in Americas, Europe most likely to be aware, perceive threat. (Survey). Gallup Poll News Service.

Anley, Y., Bogale, A., \& Haile-Gabriel, A. (2007). Adoption decision and use intensity of soil and water conservation measures by smallholder subsistence farmers in Dedo District, Western Ethiopia. Land Degradation \& Development, 18(3), 289-302. https://doi.org/10.1002/ldr.775

Arlt, D., Hoppe, I., \& Wolling, J. (2011). Climate change and media usage: Effects on problem awareness and behavioural intentions. International Communication Gazette, 73(1-2), 45-63. https://doi.org/10.1177/1748048510386741

Bohdanowicz, P. (2006). Environmental awareness and initiatives in the Swedish and Polish hotel industries-survey results. International Journal of Hospitality Management, 25(4), 662-682. https://doi.org/10.1016/j.ijhm.2005.06.006

Buloshi, A. S. A., \& Ramadan, E. (2015). Climate Change Awareness and Perception amongst the Inhabitants of Muscat Governorate, Oman. AJCC, 4(4), 330-336. https://doi.org/10.4236/ajcc.2015.44026

Das, S. (2016). Television is More Effective in Bringing Behavioral Change: Evidence from Heat-Wave Awareness Campaign in India. World Development, 88(C), 107-121. https://doi.org/10.1016/j.worlddev.2016.07.009

Government of India. (2008). National Action Plan on Climate Change. India: Prime Minister's Council on Climate Change.

Grob, A. (1995). A structural model of environmental attitudes and behaviour. Journal of Environmental Psychology, 15(3), 209-220. https://doi.org/10.1016/0272-4944(95)90004-7

ICEM. (2009). Forum report: Mekong Delta climate change forum 2009: International Centre for Environmental Management.

Klein, R. J. T., Nicholls, R. J., Ragoonaden, S., Capobianco, M., Aston, J., \& Buckley, E. N. (2001). Technological Options for Adaptation to Climate Change in Coastal Zones. Journal of Coastal Research, 17(3), 531-543. https://doi.org/10.2307/4300206

Kuhn, B., \& Yangyong, Z. (2014). Survey of experts on climate change awareness and public participation in China. Journal of Current Chinese Affairs, 43(1), 177. https://doi.org/10.1177/186810261404300107 
Maddison, D. (2006). The perception and adaptation to climate change in Africa. Centre for Environmental Economics and Policy in Africa. University of Pretoria.

Mandleni, B., \& Anim, F. D. K. (2011). Climate Change Awareness and Decision on Adaptation Measures by Livestock Farmers in South Africa. Journal of Agricultural Science, 3(3), 258-268. https://doi.org/10.5539/jas.v3n3p258

Maponya, P., Mpandeli, S., \& Oduniyi, S. (2013). Climate Change Awareness in Mpumalanga Province, South Africa. Journal of Agricultural Science, 5(10), 273-282. https://doi.org/10.5539/jas.v5n10p273

Ministry of Natural Resources and Environment. (2008). National target program to response to climate change. Ha Noi: Minstry of Natural Resources and Environment.

Ministry of Natural Resources and Environment. (2016). Climate change and sea level rise scenarios for Vietnam. Ha Noi.

Nzeadibe, T. C., Egbule, C. L., Chukwuone, N. A., \& Agu, V. C. (2011). Climate change awareness and adaptation in the Niger Delta Region of Nigeria. African Technology Policy Studies Network, Nairobi.

O’Brien, K., Leichenko, R., Kelkar, U., Venema, H., Aandahl, G., Tompkins, H., . . West, J. (2004). Mapping vulnerability to multiple stressors: Climate change and globalization in India. Global Environmental Change, 14(4), 303-313. https://doi.org/10.1016/j.gloenvcha.2004.01.001

Odjugo, P. (2013). Analysis of climate change awareness in Nigeria. Scientific Research and Essays, 8(26), 1203-1211. https://doi.org/10.5897/SRE11.2018

Oranop-na-Ayuthaya, P. (2015). Raising Climate Change Awareness of Communities in the Lower Mekong Basin. USAID Mekong Adaptation and Resilience to Climate Change. USAID.

Oranop-na-Ayuthaya, P., \& Lehman, S. (2015). Improving Women's Awareness of Climate Change. USAID Mekong Adaptation and Resilience to Climate Change. USAID.

Palmer, J. A., Suggate, J., Robottom, I., \& Hart, P. (1999). Significant life experiences and formative influences on the development of adults' environmental awareness in the UK, Australia and Canada. Environmental Education Research, 5(2), 181-200. https://doi.org/10.1080/1350462990050205

Partanen-Hertell, M., Harju-Autti, P., Kreft-Burma, K., \& Pemberton, D. (1999). Raising environmental awareness in the Baltic Sea area. The Finnish Environment 327. Hämeenlinna: The Finnish Environment.

Picketts, I., Curry, J., Déry, S., \& Cohen, S. (2013). Learning with practitioners: Climate change adaptation priorities in a Canadian community. Climatic Change, 118(2), 321-337. https://doi.org/10.1007/s10584-012-0653-8

Shahid, Z. (2012). Climate Change Awareness and Adaptation by Local Planning in Punjab, Pakistan (Doctor of Philosophy). University of Western Sydney, Australia.

Stabler, M. J., \& Goodall, B. (1997). Environmental awareness, action and performance in the Guernsey hospitality sector. Tourism Management, 18(1), 19-33. https://doi.org/10.1016/S0261-5177(96)00095-7

Tran, T. (2012). Climate change scenarios for Vietnam. WISDOM 5th PhD Scientific Seminar. Can Tho: WISDOM.

Tran, T. (2017). Challances of the Mekong Delta under climate change. Sustainable development for Mekong Delta to adaptation climate change. Can Tho.

USAID. (2015). USAID Mekong Adaptation and Resilience to Climate Change. Retrieved September 15, 2015, from http://www.mekongarcc.net/

Ziadat, A. H. (2010). Major factors contributing to environmental awareness among people in a third world country/Jordan. Environment, Development and Sustainability, 12(1), 135-145. https://doi.org/10.1007/s10668-009-9185-4

\section{Copyrights}

Copyright for this article is retained by the author(s), with first publication rights granted to the journal.

This is an open-access article distributed under the terms and conditions of the Creative Commons Attribution license (http://creativecommons.org/licenses/by/4.0/). 